\title{
Some polyvalent intra- and inter-textualities in Fasti 3
}

The voluminous nature of Ovid's corpus lends itself to the study of intratextuality, as does the poet's self-aware style. The Fasti is a particularly rich field for such examination, partly becomes it appears late in the poet's life so there is a large amount of material to recall, but especially because the poem itself belongs to two periods. Initial composition was alongside the Metamorphoses - these were the works Ovid was working on before he was dispatched to Tomi, ${ }^{1}$ and each shows awareness of the other; ${ }^{2}$ but the published version, addressed to Germanicus, is Tiberian, and explicitly refers to his exile in book 4 (79-84). Consequently, by the time he issued the work readers were in a position to observe any links with most of the books of exile poetry. We cannot know in most cases whether the text of the Fasti has been left unchanged since the departure from Rome in A.D. 8; but leaving a text unchanged is an authorial decision, and it is quite possible for a passage of the Tristia to allude to the Fasti and the same passage of the Fasti to allude to the same passage of the Tristia. ${ }^{3}$

One place where we can see such developments is in the aetion for the Salii and the ancilia in Fasti 3.259-392. King Numa is depicted as a man of peace, author of a calendar, keen to promote legal and religious order, dealing with thunderbolts, and engaging in conversation with various gods: he offers numerous analogies for Ovid himself, as the peaceful poet, erstwhile decemvir, and author of the Fasti. When banished Ovid is himself the victim of a lightning strike; and in exile he writes Tristia 2 and other passages addressed to Caesar, and thus becomes, like Numa, a 'man not to be excluded from conversation with the gods' (Fasti 3.344). The analogy in situation may originate in coincidence, but he exploits it in the

\footnotetext{
${ }^{1}$ Note the parallel phrasing at Tristia 2.552 sors mea rupit opus ('my fate interrupted the work') of the incomplete Fasti and 1.7.14 fuga rupit opus ('exile interrupted the work') of the Metamorphoses. The difference is that the Met. is published and available in Rome as Tristia 1.1, 1.7 and the iubeas legi ('have it read to you') of 2.558 demonstrate, whereas there is no evidence that Fasti has been issued: in Tristia 2 he says only scripsi ('I have written').

${ }^{2}$ Nicely established by Hinds 1987, e.g.

${ }^{3}$ There is some similarity in the relationship between the Amores and the other early works. In book 3 the first and the final poem both express the intention to write tragedy; but 2.18 refers to tragedy as already having grown through the poet's efforts (cura,13). The implication is that this poem was written for the second edition, and so can refer back to the Medea as already composed. However, the effect is less interesting and creative in this case: we do not have a text of the Medea from which to trace allusions in either direction; and there is no other solid evidence for late composition in the Amores, nor any crucial biographical or historical event to inform our reading. The same is true of the references to Ars amatoria and Heroides in 2.18.19-20 and 21-6. More expressive is the implied dating of the revised first book of Ars amatoria to autumn 2 B.C. (Hollis 1977, xiii and 150-1), which pointedly places it in the year of the exile of the elder Julia. But the political edge is more significant than intratextual complexities.
} 
Tristia, and by the time the Fasti was published in its revised form, the intratextualities have become significant.

Two words expressing what is 'permissible' play a key role in the passage: fas (3.314) and licet (3.326). ${ }^{4}$ From its very title the Fasti is a poem that concerns itself with what is permitted: the term implies a calendrical list of the days on which one may 'speak', i.e. legal action is allowed: cf. 1.48 fastus erit per quem lege licebit agi (n.b. 47-62), and Varro, Ling. Lat. 6.29 dies fasti, per quos praetoribus omnia uerba sine piaculo licet fari. ${ }^{5}$ Some instances of the words reflect on the poet's access to arcane knowledge and divine inspiration, e.g. 3.167 si licet occultos monitus audire deorum / uatibus ('if poets are allowed to hear the advice of gods') and 6.7-8:

fas mihi praecipue uoltus uidisse deorum, uel quia sum uates, uel quia sacra cano. ${ }^{6}$

However, licet is a key term in the exile poetry from the first couplet on (Trist. 1.1.1-2):

Parue, (nec inuideo) sine me, liber, ibis in Vrbem, ei mihi, quo domino non licet ire tuo. ${ }^{7}$

The terms thus come to evoke the restrictions placed on Ovid as an exile; and all the more so given that licet and fas appear as a pair together in a couplet marked as late because it is addressed to Germanicus (Fasti 1.25-6):

si licet et fas est, uates rege uatis habenas, auspice te felix totus ut annus eat. ${ }^{8}$

In asking gods for forgiveness because of the known innocence of his character, the Ovid of exile is figured as Numa addressing first Picus and Faunus (Fasti 3.309-10):

tum Numa: di nemorum, factis ignoscite nostris si scelus ingenio scitis abesse meo. ${ }^{9}$

\footnotetext{
${ }^{4} \mathrm{Cf}$. also 3.325 scire nefas homini. nobis concessa canentur ('<these things $>$ it is not right for a man to know. We shall sing what is permitted').

${ }^{5}$ Varro has similar formulations at Ling. Lat. 6.30, 53. Ovid reprises the diction at Fasti 1.289 quod tamen ex ipsis licuit mihi discere fastis ('what it has been possible for me to discover from the Fasti themselves'). For discussion of the theme see Feeney 1992.

6 'It is right for me in particular to have seen the faces of the gods, both because I am a poet and because I sing of holy ritual.'

7 'Little book, you shall go to Rome without me (I am not envious); alas that is a place where it is not permitted to your master to go.' Cf. e.g. 1.1.16, 57; 1.3.67-8; 3.12.26, 3.14.12; 5.4.3; Ex Ponto 2.2.8, 3.4.68, 4.4.45. fas appears e.g. at Tristia 2.515, 3.1.81, Ex Ponto 4.8.55, 4.16.45.

8 'If is permitted by human law and divine, as a poet guide the reins of a poet so that the whole year may pass propitiously under your auspices.'
} 
and then Jupiter himself (3.333-6):

ut rediit animus, da certa piamina, dixit,

fulminis, altorum rexque paterque deum,

si tua contigimus manibus donaria puris,

hoc quoque quod petitur si pia lingua rogat. ${ }^{10}$

Forgiveness is a theme already at Trist. 1.1.71 ignoscant augusta mihi loca dique locorum ('may I be pardoned by the august place and the gods of the place'); and the poet's lack of wickedness and fundamental innocence is repeatedly asserted. Both appear together at Trist. 1.2.97-105 when he appeals to the gods of the Adriatic to let him pass through the storm:

si tamen acta deos numquam mortalia fallunt,

a culpa facinus scitis abesse mea.

immo ita si scitis, si me merus abstulit error,

stultaque mens nobis, non scelerata fuit, ...

$$
\text { ... ita parcite, diui! }{ }^{11}
$$

Some of the language precisely recalls that of the Numa episode, especially scitis abesse mea. Ovid aggrandizes his situation by associating himself with an esteemed hero as he does throughout Tristia 1 with the evocations of Aeneas, Ulysses and the like; he wistfully evokes a figure who was able to use his wit to charm a threatening deity. Ovid can only address his Jupiter in absence, and is doubtful whether he has the right to do so at all (Tristia 5.2.45-6):

alloquor en absens absentia numina supplex,

si fas est homini cum Iove posse loqui. ${ }^{12}$

But when the exiled Ovid has established his own distinctive identity, the parallels between Numa and the poet darken the tone in the Fasti: having fas and legality on your side is insufficient in the world of Augustus.

The Ides of March was in the traditional lunar calendar the first full moon of the year, an event marked by celebration of Anna Perenna. Though the cult was an established part of the calendar, and thus sanctioned by the state, Ovid’s account at Fasti 3.523-696 says nothing about formal rites, but emphasizes the popular participation in the day and the obscene

\footnotetext{
9 'Then Numa says: "Gods of the woods, pardon our actions, if you are aware that my mind is free from wickedness.",

10 'Once his wits returned he said, "Give us a sure way of expiating the thunderbolt, king and father of the lofty gods, if we have touched your sanctuary with unsullied hands, if it is a pious tongue that makes this request too.",

11 'However, if mortal acts never escape the notice of the gods, you know that villainy is absent from my fault.

In fact, if that is what you know, if I was carried away by a simple mistake and my mind was foolish not wicked ... then spare me, gods.

12 'See, as a suppliant, in absence I address the absent gods, if a man has the right to be able to speak to Jupiter.'
} 
entertainment enjoyed by the crowds. Anna is to us a rather obscure goddess, and was apparently so in antiquity too. Ovid presents a series of different accounts of her identity: she is a symbol of on-going time (the moon or the year), a nymph of flowing water, a deity of food and fertility. But he gives the greatest space to a story that casts her as Anna the sister of Dido, familiar to us as a sympathetic figure from book 4 of the Aeneid. The narrative begins where Vergil's finishes, with Dido's death. Driven from her new homeland in Carthage by the intrusion of Iarbas, the local king, Dido’s rejected suitor, Anna finds sanctuary with Battus on Malta; but her vindictive brother Pygmalion threatens to attack and she is forced to flee again, this time towards Italy. Just as the ship approaches the shores of the Gulf of Tarentum, a sudden storm drives them far away. Finally, she is ship-wrecked on the coast of Latium, and actually finds Aeneas there, walking barefoot with Achates.

Recognizing her, he offers regrets and hospitality, and takes her home. He commends her to the care of Lavinia, but the queen is suspicious of the exotic arrival from her husband's past, and plots to kill her. The ghost of Dido warns Anna to escape; she leaps from the window, runs across the fields, and finds a permanent home in the waters of the Numicius. When the locals search for her, a voice is heard from the river (3.653-4):

ipsa loqui uisa est: placidi sum nympha Numici:

amne perenne latens Anna Perenna uocor. ${ }^{13}$

Anna's drowning in the ever-flowing river has immortalized her: as a result of the union amnis becomes Anna, and she becomes perennis. The perennial river symbolizes the everflowing nature of time, and thus of the goddess of the year.

Analogies with the Aeneid are obvious: exiled from her home in Tyre, like the Trojans after the sack of Troy, Anna's attempts to settle are repeatedly thwarted by events: the episode 'at first sight appears to be a continuation, completion, and replica of the Aeneid' (Barchiesi 1997: 21), and virtually every couplet can be related to something within the Aeneid. ${ }^{14}$ But there is considerable play with the elegiac here, and the opening lines (545-50) give a very Ovidian twist ${ }^{15}$ to Aeneid 4:

arserat Aeneae Dido miserabilis igne,

\footnotetext{
${ }^{13}$ She herself was heard to speak: 'I am the nymph of the calm Numicius. Hidden in the perennial stream, I am called Anna Perenna.'

${ }^{14}$ Like the Ariadne story (3.459-516) this self-aware sequel, engaging in insightful reading of a predecessor, has received much critical attention: see Döpp 1969: 56-76; Porte 1985: 144-8; Brugnoli 1991; Pfaff-Reydellet 2002: 955-8; Murgatroyd 2005: 105-6, 114-15, 121-31; Tronchet 2014; Chiu 2016: 72-86. It too marks its imitation with reference to, and evocation of, repetition (545-6, 554, 563, 613) and memory (553, 612, 623). ${ }^{15}$ The reduction of the whole book to a single couplet is reminiscent of the epigrammatic synopses of Aeneid 4 and 6 at Met. 14.78-81, 116-19.
} 
arserat exstructis in sua fata rogis,

compositusque cinis, tumulique in marmore carmen

hoc breue, quod moriens ipsa reliquit, erat:

PRAEBVIT AENEAS ET CAVSAM MORTIS ET ENSEM:

IPSA SVA DIDO CONCIDIT VSA MANV. ${ }^{16}$

The anaphora arserat ... arserat brings out the theme of fire that dominates Vergil's book: here we can see Ovid the literary critic, producing in one evocative couplet the significance that a modern critic might elucidate in several pages of a learned journal. There is a kind of syllepsis as the force of the verb changes from psychological in the hexameter to physical in the pentameter. This matches the move in the Aeneid from the metaphor of love as fire to the reality of Dido’s pyre, constructed and set alight towards the end of book 4, and seen burning from the sea by Aeneas at the start of book 5. From love and death he naturally moves to the funeral, another elegiac topic, and commemoration through an epitaph, a 'short' poetic form (n.b. breue), and one that reprises not Virgil's epic, but, in an audacious moment of literary one-upmanship, Ovid's own elegiac letter. He quotes as Dido's the epitaph that he himself had written at the climax of Heroides 7 (193-6)

nec consumpta rogis inscribar Elissa Sychaei;

hoc tantum in tumuli marmore carmen erit:

PRAEBVIT AENEAS ET CAVSAM MORTIS ET ENSEM:

IPSA SVA DIDO CONCIDIT VSA MANV. ${ }^{17}$

The Fasti lines confirm that Dido's instructions have been carried out precisely (note the echo of in tumuli marmore carmen, Ep. 7.194); presumably this has been done by Anna, the explicit addressee at Ep. 7.191. The syllepsis PRAEBVIT ... ET CAVSAM MORTIS ET ENSEM emphasizes the fact that the sword with which Dido kills herself is the one left by Aeneas in her bedroom. The epitaph answers the question Aeneas had posed to her ghost when they met in the underworld at Aen. 6.458 funeris heu tibi causa fui? ('Alas, was I the cause of your death?'). Next Iarbas invades (551-2), but even he is cast in the role of a spurned lover (5534):

protinus inuadunt Numidae sine uindice regnum, et potitur capta Maurus Iarba domo, seque memor spretum, thalamis tamen, inquit, Elissae

\footnotetext{
16 'Unhappy Dido had burned with fire for Aeneas, she had burned on the pyre constructed for her end, and the ash had been collected, and on the marble of her tomb there was this epigram, which she had herself left when she died: AENEAS PROVIDED THE CAUSE OF DEATH AND THE SWORD; BUT DIDO FELL USING HER OWN HAND.' 17 'Nor when consumed by the pyre shall I be inscribed as Elissa wife of Sychaeus; only this couplet will be on the marble of the tomb: AENEAS etc.'
} 
en ego, quem totiens reppulit illa, fruor. ${ }^{18}$

The Carthaginians’ flight is described with an epic simile (555-6):

diffugiunt Tyrii quo quemque agit error, ut olim

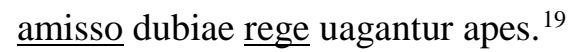

However, the picture of bees dispersing when their queen dies takes us, via the simile comparing Carthage to the hard-working, organized hive of spring-time in Aeneid 1.430-6, back to the small scale of Georgics 4, and especially the grimmer picture of 4.212-14:

rege incolumi mens omnibus una est;

amisso rupere fidem, constructaque mella

diripuere ipsae et cratis soluere fauorum. ${ }^{20}$

As Anna says farewell to her sister's ashes (559-64), the quasi-funeral is once again conducted in elegiac language. Her voyages, first to Malta, then to Italy, inevitably provide more epic material (including a simile at 584), but unlike epic heroes she travels without divine intervention or guidance, ${ }^{21}$ she does not visit the land of Mars ${ }^{22}$ nor Jupiter's birthplace Crete, nor does she encounter monsters like the Harpies, Polyphemus, or Scylla and Charybdis; but for three years she lives on Malta, small as it is (572), the guest of Battus, an unwarlike king, whose name recalls Callimachus (son of Battus), and who hates arms and speaks only in pentameters. ${ }^{23}$ However, Anna's wicked brother Pygmalion restores the epic tone, threatening war. Once again she sets sail, to be driven off course by a great storm. Like Aeneas and Odysseus she wishes she had died on land (597-8). Once she reaches Latium, however, there is no magic cloud to obscure her identity (contrast Od. 7.14-17, Aen. 1.41114), and the recognition scene happens with comic immediacy (Anna est, exclamat Achates, 607). Aeneas reminisces about his epic past (613-20), but he has the bare feet of an actor from low-brow drama (604), and he speaks elegiacs, notably mannered ones at 623-4: multa tibi memores, nil non debemus Elissae:

nomine grata tuo, grata sororis eris. ${ }^{24}$

\footnotetext{
18 "Immediately the Numidians invade the kingdom that lacked a protector, and Moorish Iarbas occupied the house he had captured, and, remembering that he had been scorned, said "Behold I whom she rejected so often yet enjoy the bedroom of Elissa." ,

19 'The Tyrians flee where their wandering takes each of them, as sometimes bees wander uncertainly when the queen is lost.'

20 'When the queen is unharmed, they share a single mind; when she is lost, they break their bond, and themselves tear apart the honey they have made and dissolve the construction of the honeycomb.'

${ }^{21}$ Tronchet $2014 \S 52$.

${ }^{22}$ Aeneas describes Thrace as terra Mauortia at Aen. 3.13.

${ }^{23}$ Barchiesi 1997: 22.

24 'We owe much to you, everything to Dido, I remember: you will be welcome in your own name, and your sister's.'
} 
Though the appearance of Dido’s ghost to warn Anna seems an epic moment and there is a final simile at 646, the generic affiliations as the story plays out are contested between tragedy (the traveller is threatened by the local queen, as Menelaus and Orestes by the local king in Euripides' Helen and Iphigenia in Tauris) and adultery mime: mime wins, as Anna jumps out of the window half-dressed (643-5) and comes to a happy end in the waters of the Numicius (653-6). Unlike Aeneas - no one tells stories about Indiges — she retains her identity and has life as a goddess, tricking Mars into confusing her with Minerva, and enjoying the joke (677-96).

I turn now to verses 557-9:

tertia nudandas acceperat area messes,

inque cauos ierant tertia musta lacus: pellitur Anna domo; $\ldots{ }^{25}$

After the general dispersal of the Carthaginians (diffugiunt Tyrii, 555), the narrative turns its focus to the key individual. But why should Anna delay three years, especially when the aggressive Iarbas is sleeping in her sister's bedroom? Murgia 1987 saw that the lines do not belong where transmitted, but with 575-6, where the length of Anna's stay with Battus is described as lasting into the third year:

tertia nudandas acceperat area messes,

inque cauos ierant tertia musta lacus;

signa recensuerat bis sol sua, tertius ibat

annus, et exilio terra paranda noua est:

frater adest belloque petit. ${ }^{26}$

Compare the similar account given by Silius, at Punica 8.61-3:

atque ea, dum flauas bis tondet messor aristas,

seruata interea sedes: nec longius uti

his opibus Battoque fuit. ${ }^{27}$

The Punica has had no delay in Carthage: in 8.54-5 (regnis se imponit Iarbas / et tepido fugit Anna rogo) Iarbas arrives, and immediately Anna leaves, while Dido’s pyre is still warm. Reducing to one the groups of three years also fits the chronology of the Aeneid. In Jupiter's

\footnotetext{
25 'For the third time the threshing floor had received the harvest to strip it of its husk, and for a third time the new vintage had gone into hollow vats: Anna is driven from her home ...'

26 'For the third time the threshing floor had received the harvest to strip it of its husk, and for a third time the new vintage had gone into hollow vats; the sun had twice reviewed the signs of the zodiac and the third year was progressing, and she had to find a new land for her exile: her brother comes and seeks her through war.' ${ }^{27}$ 'And that home is kept while the reaper twice shears the golden corn; but it was not possible any longer to use Battus and the resources there.'
} 
speech of consolation to Venus in book 1, he describes the period of Aeneas' reign in Latium in similar terms (1.263-7):

bellum ingens geret Italia populosque ferocis

contundet moresque uiris et moenia ponet,

tertia dum Latio regnantem uiderit aestas

ternaque transierint Rutulis hiberna subactis.

at puer Ascanius ... ${ }^{28}$

Aeneas shall fight the locals when he arrives in Italy, and he shall win, Jupiter reveals; then he shall start establishing his city - until three years have passed. He does not spell out to Venus what happens then, but that is simply tact: he can move on to the positive image provided by the succession of Iulus, and his descendants, the Julian gens. But the clear implication is that Aeneas will die, as he does, for example, in the account of Dionysius of Halicarnassus. $^{29}$ If Anna only reaches Italy in the sixth year, Aeneas should be dead, on Vergil's, and on the traditional, chronology; the emphatic way in which the passing of three years is again expressed by Ovid strongly implies that he is following Vergil, whereas confusion is all that results from our maintaining 3.557-8 in their transmitted position. ${ }^{30}$ Anna thus sails on from Malta in the third year after her sister's death.

When she is ship-wrecked on the coast of Latium, and meets Aeneas, he is described in 603-4 as going on a secret journey barefoot, accompanied only by Achates:

litore dotali solo comitatus Achate

secretum nudo dum pede carpit iter, aspicit errantem ... ${ }^{31}$

The passage never explains the couplet, and we should ask what the strange details imply. Scholars have offered a variety of explanations for the lack of shoes: it is a sign of primitive

\footnotetext{
28 'He shall wage a great war in Italy and crush fierce races and establish practices and a city for the people, until the third summer has seen him reigning in Latium and the third winter has passed since he subjugated the Rutulians. The boy Ascanius ...'

${ }^{29}$ Rom. Ant. 64.3-5: three years after the war against Turnus, and three years into his reign. In other respects the account is different: Aeneas becomes king only after the death of Latinus in the same war.

${ }^{30}$ Monhardt 1994 observes that the sequence produced by Murgia's transposition is a strange one, in which three years had apparently passed (557-8), but then only two (575). The rhetoric is odd, but the sequence is in fact logical. If we suppose that Anna has reached Malta in spring, by the time she has seen the third harvest and the third vintage, the sun has completed two full years, and is now making progress through the third. There are some further points that may be made in favour of the authenticity of 557-8, but for my current purposes, what matters is that the couplet does not belong where transmitted.

31 'On the shore that came as his wedding gift, accompanied by Achates alone, while he was treading a secluded path, barefoot, he spies <Anna $>$ wandering, ...'
} 
simplicity, ${ }^{32}$ or turns Aeneas into a mime or pantomime performer, ${ }^{33}$ just as his mother wears the buskin of tragedy when she meets Aeneas and Achates at Aen. 1.314-405. In addition nudity of the feet may indicate informality, and hint at erotic encounters: ${ }^{34}$ though these are usually set in the bedroom, Ovid depicts a number of heroines barefoot as they about to be taken up by gods: Ariadne (Ars 1.530), Persephone (Fasti 4.426), and Ilia (Am. 3.6.50). ${ }^{35}$ The evocation of Ilia is particularly important because she is a model for Anna: her story ends with her throwing herself into the river Anio and becoming a nymph. Here, however, it is Aeneas who is like Ilia. What of the secretum ... iter? Is Aeneas keen to get away from the burdens of rule? Now he has found a settled home, does he (like Tennyson's Ulysses) hanker after his old life as a traveller? Or is there a purpose here that Anna’s sudden arrival interrupts?

One possible answer is that he was heading to a meeting with his mother at the mouth of the river Numicius, an event that is described at 14.596-604 in the Metamorphoses, a poem that has so far played no part in my discussion:

gaudet gratesque agit illa parenti perque leues auras iunctis inuecta columbis litus adit Laurens, ubi tectus harundine serpit in freta flumineis uicina Numicius undis. hunc iubet Aeneae quaecumque obnoxia morti 600 abluere et tacito deferre sub aequora cursu; corniger exsequitur Veneris mandata suisque quicquid in Aenea fuerat mortale repurgat et respersit aquis; pars optima restitit illi. ${ }^{36}$

The two passages are immediately connected by the phrase Laurens litus (Fasti 3.599); and this is reinforced by the diction used to describe the Numicius in each episode, corniger in

\footnotetext{
32 So Peter 1889, ad loc.; Littlewood 1980, 311; and Delz 1994, 90 n.5: cf. Aen. 7.689, Hor. Ep. 1.19.12 siquis uoltu toruo ferus et pede nudo | ... simulet ... Catonem ('if some wild individual were to imitate Cato with grim mien and bare feet ...').

${ }^{33}$ Barchiesi (1995: 8); cf. the noun planipes (= 'barefoot'), and the implication of Seneca, Ep. 8.8 quam multa Publilii non excalceatis sed coturnatis dicenda sunt ('how many of Publilius' lines are fit to be spoken not by shoeless comedians but by booted tragic actors').

${ }^{34}$ E.g. Am. 3.7.82, Hor. Serm. 1.2.132.

${ }^{35}$ Cf. also the Nymphs at Fasti 1.410 impediunt teneros uincula nulla pedes. Of course, the Romans did enjoy walking barefoot in relaxed situations: Pliny, Ep. 2.17.15.

36 ' $<$ Venus $>$ rejoices and thanks her father, and carried by yoked doves through the light breezes she approaches the Laurentine coast where the Numicius, covered in reeds, snakes with his river waters into the neighbouring sea. Him she tells to wash off whatever in Aeneas is liable to death and to carry it down to the sea in his silent flow; the horn-bearing god carries out Venus's instructions and purges whatever was mortal in Aeneas and washed him with his waters: his best part remains.' Verses 607-8 report his cult title, Indiges.
} 
particular (Fasti 3.647). It may be relevant to this line of interpretation that ritual can require the absence of one shoe or both; ${ }^{37}$ and that gods are often depicted barefoot. ${ }^{38}$

In the Aeneid Jupiter reveals in book 1 that Aeneas will reign for three years in Latium, and at 12.794-5 the god tells Juno that she will accept him into heaven as the god Indiges:

Indigetem Aenean scis ipsa et scire fateris

deberi caelo fatisque ad sidera tolli. ${ }^{39}$

The Sibylline prophecy in Tibullus 2.5 has the same combination of information as

Metamophoses 14: Aeneas deified in the Numicius and becoming Indiges (2.5.39-44)

'Impiger Aenea, uolitantis frater Amoris,

Troica qui profugis sacra uehis ratibus,

iam tibi Laurentes adsignat Iuppiter agros,

iam uocat errantes hospita terra Lares.

illic sanctus eris, cum te ueneranda Numici

unda deum caelo miserit Indigetem. ..., 40

The Fasti has three years passing after the death of Dido, and a deification in the river

Numicius - but of Anna, not Aeneas. Or not explicitly of Aeneas: but a reader of the Fasti who combines the information given there with that from Ovid's intertexts may feel that there is something to be said for Lavinia's suspicions. Both Aeneas and Anna will become gods associated with the river Numicius, and in the same year. If we ask where Aeneas was going when they met, the answer is surely 'to the Numicius'; and if 'why does he disappear from the narrative? why does he play no part in the group hunting for Anna?', we may suppose that 'he is already there'. The upshot is succinctly given in Silius' description of Anna at Punica 8.39, diua Indigetis castis contermina lucis ('the goddess who is neighbour to the chaste groves of Indiges'). In the account offered by Dionysius, it is Aeneas' disappearance that leads to his apotheosis, and the reported inscription actually equates him with the river Numicius (Rom. Ant. 1.64.5):

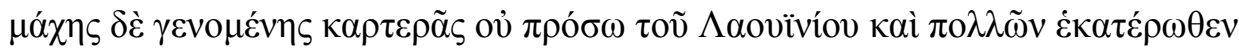

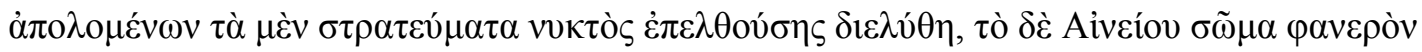

\footnotetext{
${ }^{37}$ E.g. Dido at Verg. Aen. 4.518; Medea at Ov. Met. 7.183; Columella 11.3.64.

${ }^{38}$ E.g. Bacchus at Prop. 3.17.32 feries nudos ueste fluente pedes; Mars Ultor on coins and gems; the Prima Porta Augustus, on which see Squire 2013: 266-7.

39 'You yourself know, and admit you know that Aeneas is owed to the heavens as Indiges, and to be raised to the stars according to fate.'

40 'Heroic Aeneas, brother of winged Cupid, you who carry sacred Trojan objects in migrant boats, Jupiter has already assigned the Laurentine fields to you, already the hospitable land summons your wandering Lares. There you will be sanctified when the holy water of the Numicius sends you to heaven as the god Indiges. ...'
} 


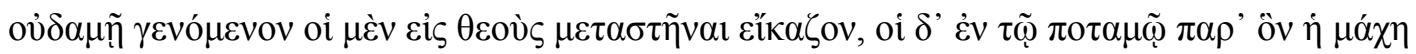

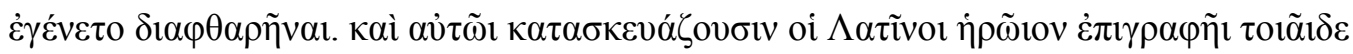

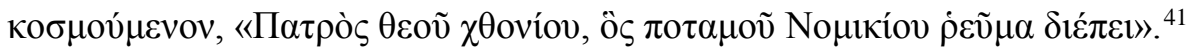

An intra- and intertextual reading thus has Anna and Aeneas, Perenna and Indiges, ending up as the deities of the Numicius, happy ever after.

Anna's story is fashioned from Aeneas's, but it is also at points significantly akin to Ovid's: both have crossed stormy seas to dangerous locations. A key word of his exile recurs at the start and end of the journey: the Carthaginians head wherever error sends them (3.555), and Anna gives an account of her errores at 3.626. The tale of Anna's exile is introduced, as we have seen, with the emphatic anaphora arserat ... arserat (3.545-6); in moments of wild fantasy, I do find myself wondering whether we might be intended to read this also as ars erat ... ars erat, and thus a statement of the existence of the Ars amatoria that was the motivation for the poet's relegation. He certainly plays on the Ars in his account of the exile of the tibia on the Quinquatrus minores in June (6.649-710). This passage of Fasti 6 is marked as exilic, both by the polysyllabic pentameter ending funeribus at 660 , and by the poignant exilium quodam tempore Tibur erat ('once upon a time exile meant Tibur'), describing the destination of the tibicines, at $666 .{ }^{42}$ At 701 Minerva says of the tibia she has invented: ars mihi non tanti est; ualeas, mea tibia ('the art is not worth so much to me; farewell, my flute'), phrasing that in context recalls Ovid's frequent rejection of his own Ars.

As we proceed through Anna's story, we keep finding reminders of Ovid's departure from Rome and his journey to Tomi. Consider Fasti 3.563-4, as she leaves Carthage:

terque uale dixit, cineres ter ad ora relatos

pressit, et est illi uisa subesse soror. ${ }^{43}$

The anaphora on ter ... ter recalls the attempts of epic figures to embrace ghosts, but the context is closer to a line describing Ovid's own departure for exile from his home, Trist. 1.3.55-6:

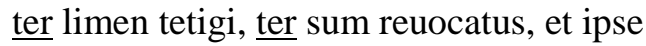

\footnotetext{
41 'A major battle took place not far from Lavinium, and many were killed on each side. The armies separated as night came on, and when the body of Aeneas was nowhere to be seen, some concluded that it had been translated to the gods, some that it had disappeared in the river besides which the battle took place. The Latins made a shrine for him, adorned with an inscription of this kind: "<Shrine $>$ of the native father god [= Indiges], who guides the stream of the river Numicius.",

${ }^{42}$ Courtney 1965, 63.

43 'And three times she said farewell, three times she brought the ashes to her face and pressed them, and she felt her sister was at hand.'
} 
indulgens animo pes mihi tardus erat. ${ }^{44}$

Moreover, the phrase uale dixit echoes the following couplet from Tristia 1.3 (57-8), which begins saepe uale dicto; saepe reworks ter:

saepe uale dicto rursus sum multa locutus,

et quasi discedens oscula summa dedi. ${ }^{45}$

In 3.565 moenia respiciens is a quotation from Aen. 5.3, of Aeneas departing from Carthage.

But by the time that Ovid publishes the Fasti he has used the participle of his own departure from his home and family at Tristia 1.3 .60 respiciens ... pignora cara, and of the group of captives seized by marauders at Tristia 3.10.62 respiciens frustra rura Laremque suum.

A number of details in the storm that hits Anna's ship recall the storms that afflict Ovid on his way to Tomi, described in Tristia 1.2, 1.4, 1.11. I shall concentrate on 3.591-6:

adsiliunt fluctus imoque a gurgite pontus uertitur, et canas alueus haurit aquas.

uincitur ars uento nec iam moderator habenis utitur, at uotis is quoque poscit opem.

iactatur tumidas exul Phoenissa per undas 595 umidaque opposita lumina ueste tegit. ${ }^{46}$

In 595 the epithet tumidus is a conventional marker of epic, especially when applied to the sea: cf. e.g. Propertius 3.9.35 non ego uelifera tumidum mare findo carina. But in this context, where the word is juxtaposed with exul, a series of instances of tumidus in Tristia 1 and 2 is equally important: $1.2 .23-4$ pontus ... fluctibus ... tumidus, 1.5 .77 tumidis ... undis, 2.18 tumidas ... aquas. Two striking details are shared with Tristia 1.11.17-18, 21-2: saepe maris pars intus erat; tamen ipse trementi carmina ducebam qualiacumque manu. ... ipse gubernator tollens ad sidera palmas exposcit uotis, immemor artis, opem. ${ }^{47}$

Both passages visualize the sea within the boat and a helmsman who gives up steering in order to raise his hands in prayer (an allusion to Aeneas at Aen. 1.93). ${ }^{48}$ In the Tristia the

\footnotetext{
44 'Three times I touched the threshold, three times I was called back, and my very foot was slow, indulging my mind's wish.'

45 'Often, having said farewell, I again said much more and gave final kisses as if departing.'

46 'Waves leap up and the sea is churned from its depths, and the hull drinks in the foaming waters. Craft is conquered by wind and the helmsman no longer uses the strings on the rudder but even he seeks aid with prayers. The Phoenician exile is tossed on the swollen waves and hides her damp eyes behind her clothing.' 47 'Often some of the sea was inside the boat; but I myself with trembling hand was composing poems, whatever their quality ... The very helmsman, raising his hands to the stars, seeks aid with prayers, forgetful of his craft.' ${ }^{48}$ The helmsman has vain recourse to prayer at Met. 11.537-42; his ars fails also at Trist. 1.2.31-2, 1.4.11-12.
} 
helmsman is pointedly contrasted with Ovid himself, the one forgetful of his art, the other still writing poems despite the storms that assail him. These storms are both real and metaphorical, the effect of the wind on the sea and of banishment on his heart, as is made clear in verses 1.11.9-10, 33-4

ipse ego nunc miror tantis animique marisque

fluctibus ingenium non cecidisse meum. ...

cumque sit hibernis agitatum fluctibus aequor,

pectora sunt ipso turbidiora mari. ${ }^{49}$

The shared phrasing uotis poscit opem interconnects the two poems; but so does the presence of the noun ars. Anna is like Ovid in facing the storms of sea and exile. However, though Ovid's Ars amatoria may have been overwhelmed by the storm of exile (cf. uincitur ars uento, Fasti 3.593), his poetic craft has not been. Encyclopaedia entries retain Jerome's date of A.D. 17 for the poet's death, and 2017 was replete with conferences to celebrate the supposed bimillennium; but there is no solid evidence for Ovid's death, and with the final words of the Metamorphoses he himself claimed per omnia saecula ... uiuam. The intratextuality should help us remember that like Anna he was an exile, and like her he is immortal.

49 'I myself am now amazed that my poetic creativity has not submitted to the enormous disturbance of mind and sea. ... And though the sea is stirred up with winter waves, my heart is more storm-tossed than the sea itself.' 